目次

令和元年電力・エネルギ一部門 「研究·技術功労賞」受賞者 1 研究グループ紹介 学界情報 海外駐在記事 調査研究委員会レポート 用語解説 $/$ 論文誌目次 学会カレンダー

タイ合同シンポジウム 発表論文募集

\title{
令和元年 電力・エネルギー部門 「研究・技術功労賞」受賞者
}

電力・エネルギー部門（B 部門）では，長年，地道な活動を続けてこられ，技術の発展に貢献された研究者または技術者の 方々の労に報いるとともに，電力・エネルギー分野技術の更なる発展を図ることを目的とし，平成 18 年から，部門表彰制度 として「研究・技術功労賞」を新たに設けております。

研究調査運営委員会および部門役員会での審査の結果，令和元年の受賞者は，次の 2 名の方に決定いたしました。表彰は， 広島工業大学で開催されました令和元年電力・エネルギー部門大会の表彰式（9月４日）で執り行われました。

岡村 幸壽 殿 〔中電技術コンサルタン

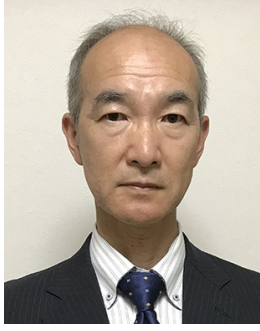

「配電系統の保護と分散型電源の連系に関する解析技術の開発およびこれら に関する課題解決への貢献」

30 年にわたり配電系統の保護と分散型電源の連系に関する解析技術の開発およびこれら に関する課題解決に貢献した。

解析技術においては，配電系統への発電機連系に伴う電圧上昇に関する現象を解明し， 電圧上昇の可能性が大きい配電線の形態を推定できる解析手法の開発および発電機が連系 された配電系統ネットワークの保護協調を解析する新たな手法の開発に精力的に取り組ん だ。

課題解決においては, 配電線事故時対応において, 光ケーブルを使用した高速制御によ る配電線事故点標定・事故区間切り離し制御方式を開発した。

これらの成果については, 電気学会 $\mathrm{B}$ 部門論文誌など数多くの論文を発表され，学術面 での功績も大きい。

また，受変電設備や分散型発電機の設計にも長年携わり，これらの経験に基づく学術発 表を多く行うほか, 後進の指導も行ってきた。さらに，国家資格取得経験をもとに，資格 取得に関連する著書を発刊され，国内での電気技術者の育成にも貢献した。

「保護リレーシステムにおけるディジタル化技術発展への貢献」

前田 隆文 殿 〔東芝エネルギーシステムズ(株)〕

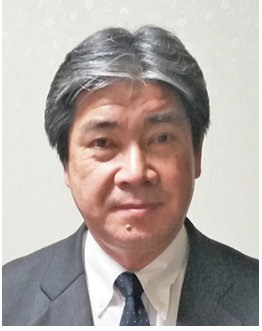

40 年以上にわたって, 電力系統の保護リレーに関する開発ならびに技術者育成に従事し ており，ディジタルリレーの発展・適用拡大に大きく貢献してきた。

特に現在のディジタルリレーの根幹をなす第二世代ディジタルリレーの規格制定ならび に安定化システムをはじめとした電力での適用拡大は, 国内のディジタルリレー技術を大 きく進展させ，保護リレ一業界への貢献は多大である。

また，長年にわたり電力業界全体として電気主任技術者を目指寸方のための問題解説講 座や，保護リレー業界における若手技術者育成にも力を注いでおり，多くの著書執筆や技 術者交流会などの活動を行ってきた。 